\title{
Crop diversification for weed management in organic arable cropping systems
}

\author{
Livija Zarina1, Barbel Gerowitt ${ }^{2}$, Bo Melander ${ }^{3}$, Jukka Salonen ${ }^{4}$, Roman Krawczuk ${ }^{5}$, \\ Teo Verwijst ${ }^{6}$ \\ ${ }^{1}$ State Priekuli Plant Breeding Institute, \\ ${ }^{2}$ University of Rostock, Rostock, Germany, \\ ${ }^{3}$ Aarhus University, Denmark, \\ ${ }^{4}$ Natural Resources Institute, Jokioinen, Finland, \\ ${ }^{5}$ Institute of Plant Protection, Poland, \\ ${ }^{6}$ Swedish University of Agricultural Sciences, Uppsala, Sweden \\ Contactpoint. Address: Zinatnes 2, Priekuli, LV-4126, Latvia
}

\begin{abstract}
Within the ERA-net CORE Organic Plus transnational programmes supported project PRODIVA producing of the information required for a better utilization of crop diversification for weed management in North European organic arable cropping systems was started. To fulfill the goal of this project- not to eradicate weed problems, which is unlikely to happen in any arable farming system, but to maintain a diversified and manageable weed flora that can support beneficial organisms- there were data from ongoing long-termed cropping system experiments from Latvia analyzed.

It is hypothesised that: a) perennial weeds can be suppressed in the post-harvest period by improved cover crop establishment and pertinent selection of cover crop species; b) on-farm practices of crop diversification are related to weed pressure and species composition.

On the bases on data from organic farm and ongoing long-termed cropping system experiment on weed dynamics in six-field crop rotations with cover crop was concluded that red clover as cover crop after the harvest period is effective to manage perennial weeds. In crop rotation with higher proportions of cereals weed infection growth in sixfield rotation with $50 \%$ share of cereals up to 3.4 , but with $33.3 \%$ share-up to 2.1 times.
\end{abstract}

Keywords: crop diversification, organic farming, weeds, PRODIVA.

\section{INTRODUCTION}

Crop productivity in organic cropping systems in Northern Europe is largely constrained by weed infestations [10]. Perennial weeds are usually most detrimental to crop yield and quality, whilst many annual weed species are less harmful. Despite the need for weed management to preserve crop yield, organic cropping systems strongly contribute to maintain and support diverse weed communities on arable fields (with no selection pressure posed by herbicides) [6].

Considerable research has been allocated to develop new and direct weed control methods and strategies to reduce immediate weed problems in the crops [5]. These methods are either mechanical or thermal weeding devices some of which consume considerable fossil energy and may have adverse effects on soil structure and beneficial organisms [1]. Direct control actions are motivated to instantly release the crop from weed interference. However, the reliance on direct tactics could be reduced through careful and pertinent planning of cropping systems that mitigate severe weed problems and create a more balanced and manageable weed flora [6].

Currently, organic cropping systems are mainly planned according to the prevailing commodity prices and the need for nutrient supplies. The potential of diversifying the cropping system, not only by changing the choice of main crops, but also through the introduction of improved methods for catch/cover crops establishment $[7,11]$, has not been exploited in practise. This is mainly because the knowledge is relatively scarce. Careful planning of crop sequences is known to disrupt weed communities, especially of annual weeds [2]. Perennial weeds can also be manipulated through crop choice and by making room for control actions whenever needed [7].

For any practical implementation of crop diversification, farmers need to pay attention to the most severe weed problems. Thus, they need to distinguish between major groups of weed species

ISSN 1691-5402 
having either high or low noxiousness or being even neutral to positive for the cropping system [3, 9].

Crop diversification methods should focus on the species with high noxiousness, while maintaining diversity within the non-detrimental section of the weed assembly. Crop diversification methods will act on weeds differently, depending on regional conditions.

To fulfill tasks of the ERA-net CORE Organic Plus transnational programs supported project PRODIVA (Crop diversification and weeds) data from organic farm practices and ongoing long-termed cropping system experiments on weed dynamics in crop rotation with cover crop to produce information for weed management in North Europa were summarized from two locations in Latvia.

\section{MATERIALS AND METHODS}

\section{Fields}

Weed survey at organic farm 'Kelmeni' (OFK) (57 $\left.15^{\prime} 14.57^{\prime \prime N}, 26^{\circ} 9^{\prime} 13.01^{\prime \prime E}\right)$ and at State Priekuli Plant Breeding institute (SPPBI) $\left(57^{\circ} 18^{\prime} 49^{\prime \prime N}\right.$, $25^{\circ} 20^{\prime \prime E}$ ) was carried out in 2008 and 1014 in organic crop rotations, characterized by sod-podzolic loamy sand soils both locations (Table 1). Agrochemical parameters were determined by the State Plant Protection Service of Latvia in 2008 and 2014: the soil $\mathrm{pHKCl}$ was measured potentiometrically, humus content- Tyurin, and plant available phosphorus and potassium using Egner-Riehm methods.

Table 1.

SOIL CHARACTERISTICS OF EXPERIMENTAL FIELDS

\begin{tabular}{|c|c|c|c|c|}
\hline \multirow{2}{*}{$\begin{array}{c}\text { Soil } \\
\text { characteristic: }\end{array}$} & \multicolumn{2}{|c|}{ OFK } & \multicolumn{2}{|c|}{ SPPBI } \\
\hline & 2008 & 2014 & 2008 & 2014 \\
\hline $\mathrm{pH}_{\mathrm{KCl}}$ & 5.8 & 5.6 & 5.7 & 5.6 \\
\hline humus, $\mathrm{g} \mathrm{kg}^{-1}$ & 22 & 24 & 25 & 21 \\
\hline $\mathrm{P}_{2} \mathrm{O}_{5}, \mathrm{mg} \mathrm{kg}^{-1}$ & 159 & 134 & 128 & 126 \\
\hline $\mathrm{K}_{2} \mathrm{O}, \mathrm{mg} \mathrm{kg}^{-1}$ & 143 & 152 & 135 & 109 \\
\hline
\end{tabular}

Soil and weed management

Fields have been organically managed since 2003. As the basic soil fertility management measure was green manure (Table 2). Additionally the enriching of soil is achieved by cultivating clover as the improvement through the nitrogen fixation, as well as by turning the plant residues into the soil.

Table 2. SOIL AND WEED MANAGEMENT

\begin{tabular}{lccl}
\hline Location: & $\begin{array}{l}\text { Amount } \\
\text { of N, } \\
\mathrm{kg} \mathrm{ha}^{-1}\end{array}$ & $\begin{array}{l}\text { Weed } \\
\text { management }\end{array}$ \\
\hline $\begin{array}{l}\text { Organic farm KELMENI } \\
(O F K)\end{array}$ & 19.7 & No \\
$\begin{array}{l}\text { State Priekuli } \\
\begin{array}{l}\text { Institute } \\
(S P P B I)\end{array}\end{array}$ & Blant & 26.5 & Harrowing \\
\hline
\end{tabular}

\section{Weed assessment}

Weed assessment was carried out in fields with winter rye (OFK) and with spring barley (SPPBI) in last week of June in 2008 and 2014. The weed numbers of each individual weed species were recorded using a $0.20 \mathrm{~m}^{-2}$ frames (Fig.1). The occurrence of each weed species was recorded as percentage frequency by the method of A. Rasins and M.Taurina [4].

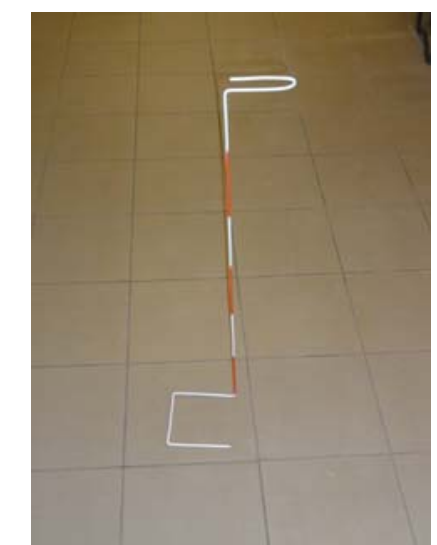

Fig. 1. Frame used for weed inventory (Photo by LAAPC)

The species were assigned to weed groups on the basis of life form (annual or perennial) and morphological characters (dicotyledonous or monocotyledonous). Weed numbers were recalculated to per $\mathrm{m}^{2}$. Weed dynamic after full rotation (six year period) were calculated and expressed as percentage of the total weed number. Dispersion around the average weed number was assessed using the standard error.

To compare weed occurrence and dynamic there was determined the proportion of cereals in rotation that was $33.3 \%$ in OFK and $50 \%$ in SPPBI, accordingly.

\section{Crop rotation at OFK:}

Winter rye with red clower as undersown- red clover (mulch)- red clover (green manure)- winter rye with red clower as undersown- red clower;

\section{Crop rotation at SPPI:}

Spring barley- crucifers for green manure (oil radish)- spring barley with clover as undersown- red clover- winter rye- potatoes.

\section{RESULTS AND DISCUSSION}

\section{Density of weeds}

The average density of weeds was 94.2 plants $\mathrm{m}^{-2}$ $\left(\mathrm{S}_{\mathrm{AV}}= \pm 14\right)$, ranging from 12 to 165 at OFK and 24 to 231 plants $\mathrm{m}^{-2}$ at SPPBI (Fig. 2). 1.8 times less weeds were in field from crop rotation with less proportion of cereals. 




Fig. 2. The average weeds density in the fields, LSD_ 28

The results shows that amount of weeds in both sites in the first survey (in 2008) were comparatively low (in average 60 plants $\mathrm{m}^{2}$ ) and similar (difference between locations- 6 plants), whereas after a full rotation (6 years from 2008 till 2014) density of weeds increases and difference between studied crop rotation is significant.

Since fewer weeds in the field from crop rotation where no harrowing which is typical physical weed control method, there is the reason believe that including of red clover in crop rotation as cover and mulch crop is an effective weed management method.

\section{Weed groups}

At the weed assessment in winter rye annual dicotyledonous species were dominant both surveys years (Fig.3). Similarly tendency was also in spring barley; however, there were significant differences in proportional distribution.

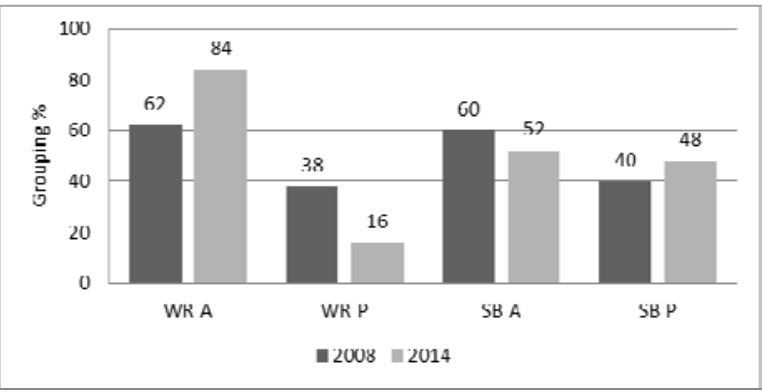

Fig. 3. Weed groups on the bases of morphological characters WR-A: winter rye- annual dicotyledonous species; WR-P: winter rye- perennial dicotyledonous species, SB-A: spring barley- annual dicotyledonous species; CB-P: spring barley- perennial dicotyledonous species

In average, between the five dominant annual dicotyledonous weed species were Chenopodium album L. (20.6 \pm 5.1 plants $\left.\mathrm{m}^{2}\right)$, Viola arvensis (Murray; $9.9 \pm 3.5$ plants $\mathrm{m}^{2}$ ), Capsella-bursa pastoris (L) $\left(5.4 \pm 1.4\right.$ plants $\left.\mathrm{m}^{2}\right)$, Stellaria media (L) $(2.8 \pm$ 0.8 plants $\left.\mathrm{m}^{2}\right)$, Thlaspi arvense $(\mathrm{L})(1.3 \pm 0.4$ plants $\mathrm{m}^{2}$ ), Fig.4.

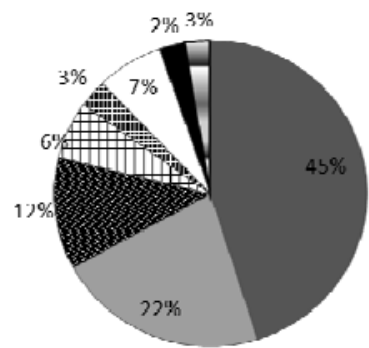

口CHEAL

IVIOAR

a (iNRIII)

\#SIFM

国 I HI $\wedge$ K

$\sqcup$ HIYKF

- CIRAR

ISONAR

Fig. 4. Share of the dominant annual and perennial weed species, $\%$

CHEAL- Chenopodium album L., VIOAR- Viola arvensis (Murray, CABP-Capsella-bursa pastoris (L), STEME- Stellaria media (L), THLAR- Thlaspi arvense (L), ELYRE- Elymus repens (L.), CIRAR- Cirsium arvense (L) (Scop.), SONAR- Sonchus arvense $(\mathrm{L})$.

There were three dominant perennial weeds fixed: Elymus repens (L.) (Gould) $\left(3.1 \pm 0.8\right.$ plants $\left.\mathrm{m}^{-2}\right)$, Cirsium arvense (L) Scop.) (1.2 \pm 0.5 plants $\left.\mathrm{m}^{-2}\right)$, and Sonchus arvense (L) $\left(0.3 \pm 0.09\right.$ plants $\left.\mathrm{m}^{-2}\right)$. The total amount of perennial weed species at OFK was 5 in both- 2008 and 2014, but at SPPBI- 6 and 7 plants $\mathrm{m}^{-2}$, accordingly that, taking into account results from nine year monitoring in conventional fields same region [10], can be defined as low.

Figure 5 shows that in crop rotation with less diversity of crops is smaller number of weed species.



Fig. 5. Average number of weed species depending crop rotation WR+ -winter rye with red clower as undersown, RCm- red clover (mulch), RC- red clover, SB - spring barley, CR - crucifers for green manure (oil radish), $\mathrm{SB}+$ - spring barley with clover as undersown, $\mathrm{P}$ - potatoes.

Data summarized from two organic fields in Latvia point on fact that perennial weeds may be cancelled after the harvest period improving the cover crop establishment and the appropriate choice of cover crop species (Fig.6). Red clover used as cover crop in context with weed management justifies itself. Particularly good efficiency is regarding perennial weeds which are in tune with one of the PRODIVA hypothesis. 


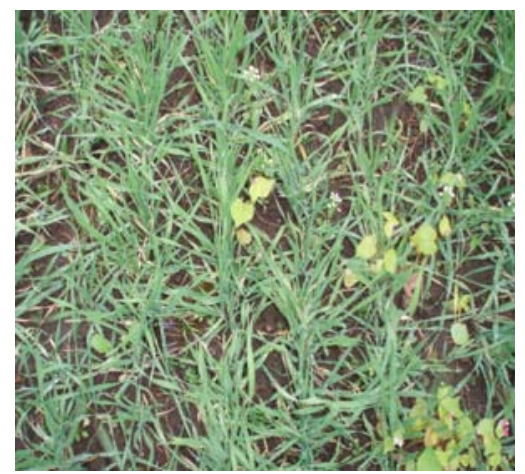

Fig. 6. Winter rye at OFK in 2011 (there were only some weeds, mainly crop contaminant- buckwheat that was sown after old ley in 2007).

\section{CONCLUSION}

In crop rotation with higher proportions of cereals weed infection growth:

- in six-field rotation with $50 \%$ share of cereals up to 3.4 times;

- in six-field rotation with $33.3 \%$ share of cereals up to 2.1 times.

In winter rye annual dicotyledonous weed species are dominant. Similar expressing also in spring barley, but there are significant differences in proportional distribution between annual and perennial dicotyledonous species.

There are no sharp differences in the spectrum of dominant weed species in both experimental sites in general; however, more weed species diversity was in rotation with more crops.

Red clover as cover crop after the harvest period is effective to manage perennial weeds. Also using red clover herbage as mulch in the previous autumn ensures effective weed management for 2-nd year clover yield, both - green mass and seed.

\section{ACKNOWLEDGMENTS}

This study was partly supported by the Ministry of Agriculture of Latvia. Project No 120308/S38.

\section{REFERENCES}

[1] Ascard, J., Hatcher, P.E., Melander, B., Upadhyaya, M.K. Thermal Weed Control. Non-Chemical Weed Management: Principles, Concepts and Technology, Wallingford, UK: CAB International, 2007, pp . 155-175.

[2] Blackshaw, R.E., Andersson, R.L., Lemerle, D. Cultural Weed Management. Non-Chemical Weed Management: Principles, Concepts and Technology, Wallingford, UK: CAB International, 2007, pp. 35-48.

[3] Gerowitt, B., Bertke, E., Hespelt, S.K, Tute, C. Towards multifunctional agriculture - weeds as ecological goods? Weed Research, 43, 2003, pp. 227-235.

[4] Lapinsh, D., Korolova, J.,Berzinsh, A. Crop rotaion influence on the weed incidence in cereals. Zemdirbyste-Agriculture, vol. 95, No. 3, 2008, pp. 433-439.

[5] Lundkvist, A., Verwijst , T. Weed Biology and Weed Management in Organic Farming. Research in Organic Farming, 2011, pp.10-41.

[6] Melander, B., Rasmussen, I.A., Barberi, P. Integrating Physical and Cultural Methods of Weed Control - Examples from European Research. Weed Science, 53, 2005, pp. 369381.

[7] Rasmussen, I.A., Melander, B., Askegaard, M., Kristensen, K., Olesen, J.E. Elytrigia repens population dynamics under different management schemes in organic cropping systems on coarse sand. European Journal of Agronomy, 58, 2014, 18-27.

[8] Storkey, J. A functional group approach to the management of UK arable weeds to support biological diversity. Weed Research, 46,2006, 513-522.

[9] Turner, R.J., Davies, G., Moore, H., Grundy, A.C., Mead, A., Organic weed management: A review of the current UK farmer perspective. Crop Protection, 26, 2007, 377-382.

[10] Vanaga, I. Dynamics of the distribution of weeds and the possibilities of their control in cereals in crop rotation in Vidzeme. Summary of the thesis for the scientific degree Dr.agr. Jelgava, 2010.59 p.

[11] Wortman, S.E., Francis, C.A., Bernards, M.A., Blankenship, E.E., Lindquist, J.L. Mechanical termination of diverse cover crop mixtures for improved weed suppression in organic cropping systems. Weed Science, 61, 2013, 162-170. 